\title{
Seasonal Variation in Physicochemical Properties of Soil within the Vicinity of an Iron Smelting Factory - Implication on Standing Vegetation
}

\author{
Olusanya Abiodun OLATUNJI ${ }^{1 *}$, Emmanuel Timilehin KOMOLAFE ${ }^{2}$, \\ Samson Olajide OKE ${ }^{2}$
}

\author{
${ }^{1}$ University of Chinese Academy of Sciences, Center for Ecological Studies, Chengdu, China; olusanya084@mails.ucas.ac.cn ("correspondingauthor) \\ ${ }^{2}$ Obafemi Awolowo University, Department of Botany, Ile-Ife, Osun State, Nigeria
}

\begin{abstract}
This study examined the seasonal variations in the physicochemical properties of soil around the vicinity of an iron smelting factory in Fashina area, Ile-Ife, with the aim of monitoring the impact on the soil characteristics, nutrient availability and its possible consequence on the surrounding vegetation. Four study plots, each measuring $50 \times 50 \mathrm{~m}$ were selected around the iron and smelting Factory. Soil samples were collected randomly and analysed during the rainy and dry seasons at a depth of $0-20 \mathrm{~cm}$, representing the top soil using soil auger. The soil samples were analysed for particle size, soil texture, $\mathrm{pH}$ and availability of some basic soil nutrient such as nitrogen, organic carbon, potassium, phosphorus, etc. The study revealed that the physicochemical properties of soil in focus varied across the plots, which may be a consequence of the gradient created by the citing of iron smelting factory, but the data obtained did not significantly varied within the seasons. Furthermore, high organic matter was recorded in all the plots under study; this might be due to the fact that the study area was rich in clay. More clayey soils generally tend to contain higher levels of organic matter, mainly because of the tendency of clays to slow down microbial degradation of organic matter, as clays form clay-humus complexes with organic matter. Also, the heavy metal distribution varied within the two seasons, as most of the metals showed high level of concentration in the rainy season.
\end{abstract}

Keywords: degradation, ecosystems, nutrient, physicochemical, terrestrial

\section{Introduction}

Soil is a natural body, differentiated into horizons of minerals and organic constituents, usually unconsolidated, of variable depth which differs from the parent material below in morphology, physical properties, chemical properties and biological characteristics (Rai, 2002). Soils are major sources for plant nutrients; however, their nutrient availability varies during the growing season depending on characteristics such as soil organic matter content, $\mathrm{pH}$ and cation-exchange capacity (Cancela et al., 2002; Strahm and Harrison, 2007).

Soil properties of terrestrial ecosystems depend upon a variety of abiotic and biotic factors that vary both spatially and seasonally (Peverill et al., 1999). Among abiotic factors, total ion content, acidity, carbon, total nitrogen and total phosphorous vary on spatial scale in the topsoil. Some additional factors like climate, land form, topography, soil texture, soil moisture and plant community also affect soil composition (Benayas et al., 2004; Takata et al., 2008).

Soil nevertheless is fundamental to every ecosystem and agricultural sustainability and production because it supplies many of the essential requirements for plant growth, including water, nutrients, anchorage, oxygen for roots and moderated temperature (Jamieson et al., 2002; van der
Maarel, 2004). Soil serves a vital function in nature, providing nutrients for plants to grow, as well as habitat for millions of micro- and macro-organisms. Healthy soil enables vegetation to flourish, releases oxygen, holds water and diminishes destructive storm runoff, breaks down waste materials, binds and breaks down pollutants, and serves as the first course in the larger food chain (Marx et al., 1999; Rodriguez-Iturbe, 2000).

Despite the significant benefit of soil to both biotic and abiotic organisms, the main threats to it are: increasing urban areas, road construction, industrial development, erosion, acidification, accumulation of pollutants, organic matter loss and deteriorating soil structure (Aweto and Ekuigbo, 1994). Soil contamination by heavy metals originate from a number of sources including geological parent material, industrial processes (atmospheric emission, waste disposal, effluent disposal) and farming practices (Ogundele, 2012). The uncontrolled input of heavy metals in soils is undesirable since once accumulated in the soil, they are generally very difficult to remove (Smith et al., 1996). This therefore causes an enormous environmental pollution problem, affecting distribution of plants and soil characteristics of an area.

In Nigeria, industries create a major source of environmental pollution due to the kind of waste they generate; some of which were discharged into rivers and 
streams untreated. Iron smelting factory is one of the medium scale industries that have just been established in Ile-Ife, Osun state, which predominantly has mostly small scale industries, commercial establishments and public institutions with just a handful of medium scale industries. Thus, a medium scale industry with potential for strong environmental pollution was situated on the outskirt of the town. However, studies have been conducted in some polluted areas of South-Western Nigeria, but nothing of such has been done on the physiochemical properties of the soil around the vicinity of Iron Smelting Factory in this part of the country.

The current study therefore hypothesise the possibility of (1) variations in the physicochemical properties of the soil, particularly within the soil characteristics and nutrient availability, due to the establishment of iron smelting factory and (2) disastrous consequence of this variation "if any" on the surrounding vegetation.

\section{Materials and Methods}

\section{The study area}

The study was carried out within the vicinity of Iron Smelting Factory in Ile-Ife, Osun State, located directly opposite Fashina village, which is $4 \mathrm{~km}$ away from the ancient city of Ile-Ife. The Iron Smelting Factory lies on latitudinal and longitudinal range of $7^{\circ}$ and $7^{\circ} 29^{\prime} \mathrm{N}$ and $4^{\circ}$ and $4^{0} 28^{\prime} \mathrm{E}$ (GPS readings). The landscape is of slightly undulating terrain and ranges in altitude between 235 and $255 \mathrm{~m}$ above sea level.

\section{Collection of soil samples}

Four study plots designated as A, B, C and D, each measuring $50 \times 50 \mathrm{~m}$, were selected around the Iron and Smelting Factory. Each of the plots was subdivided into four sub-plots measuring $25 \times 25 \mathrm{~m}$, at an increasing distance of $20 \mathrm{~m}$ away from the starting point. A quadrat of $10 \times 10 \mathrm{~m}$ was marked out within each sub-plot. In order to establish the prevailing quality of the soil in the study area, soil samples were collected and analyzed during the rainy season and in the dry season at $0-20 \mathrm{~cm}$ depth, representing the topsoil using soil auger. The soil samples were air dried at room temperature and then passed through a $2 \mathrm{~mm}$ plastic sieve to remove extraneous matter such as small pieces of brick, paving stones and other debris.

The samples were then analyzed for particle size, soil texture, exchangeable cations, nitrogen, phosphorus, organic matter content and $\mathrm{pH}$. Soil organic matter contents were determined through the determination of carbon. The organic matter contents were then calculated from the carbon content on the assumption that soil organic matter contains $58 \%$ carbon. The soil $\mathrm{pH}$ was measured in 1:1 soil-water suspension, 1:2 $0.01 \mathrm{M} \mathrm{CaCl}$, using the glass electrode $\mathrm{pH}$ meter. Total nitrogen was determined by
Kjedahl method. Total phosphorus was extracted using Mehlich extraction solution (Mehlich 3-extractable elements) through the action of acetic acid and fluoride compounds (Bray and Kurtz, 1945). Exchangeable cations were also extracted by leaching soil samples with $1 \mathrm{M}$ ammonium acetate solution; exchangeable $\mathrm{Na}$ and $\mathrm{K}$ were extracted by the action of ammonium nitrate and nitric acid and subsequently determined by flame photometer, while $\mathrm{Ca}$ was determined by Atomic Absorption Spectrophotometer. Soil particle size distribution was determined by the hydrometer method using hexametaphosphate as the dispersing agent (Bouyoucos, 1951). The presence of heavy metals such as $\mathrm{Zn}, \mathrm{Cd}, \mathrm{Pb}, \mathrm{Cu}$ and $\mathrm{Cr}$, associated with iron and steel production, was also determined using Atomic Absorption Spectrophotometer (AAS).

\section{Data analysis}

The data obtained were subjected to analysis of variance and Duncan multiple range test were employed to test significant differences among the soil physiochemical properties between the plots, for the two seasons.

\section{Results}

\section{Soil properties}

The sand content during the rainy season was the highest $(74.60 \%)$ in plot B and the lowest $(70.80 \%)$ in plot $\mathrm{D}$. The rest of the plots had intermediate values. The results showed that there was no significant difference between plot A, C and D, but plot B differed significantly from the other plots (Table 1). During the dry season, plot D recorded the lowest sand content $(72.80 \%)$, while the other sampled plots recorded intermediate sand content values. The results of soil analysis showed that there was no significant difference in the sand content for all the four plots (Table 1).

The clay content during the rainy season was the highest (17.80\%) in plot $\mathrm{D}$, closely followed by plot C (16.80\%), while plots A and B had lower clay content. The analysis results showed that there was no significant difference between plots $\mathrm{A}, \mathrm{C}$ and $\mathrm{D}$ (Table 1 ). In the dry season, the highest clay content $(17.20 \%)$ was found in plot C, while the lowest clay content $(16.2 \%)$ was recorded within plot B. The results of analysis showed that there is no significant difference in the clay content for plots A, C and D (Table 1).

The silt content during the rainy season was highest (12.00) in plot A and the lowest (3.20) in plot B. Other plots had intermediate silt content. The analysis results showed that there was no significant difference between plots $C$ and D. (Table 1). In the dry season, the highest silt content (13.00) was found in plot $A$, while the lowest (10.60) was recorded at plot B (Table 1).

Table 1. Seasonal soil particle distribution

\begin{tabular}{|c|c|c|c|c|c|c|}
\hline & \multicolumn{3}{|c|}{ Rainy season } & \multicolumn{3}{|c|}{ Dry season } \\
\hline Plot & $\%$ Sand & \% Clay & $\%$ Silt & \% Sand & $\%$ Clay & \% Silt \\
\hline $\bar{A}$ & $72.80 \pm 1.02^{\mathrm{b}}$ & $15.20 \pm 1.36^{\mathrm{c}}$ & $12.00 \pm 0.63^{\mathrm{d}}$ & $73.8 \pm 0.734^{a}$ & $16.4 \pm 1.249^{c}$ & $13.0 \pm 0.707^{d}$ \\
\hline B & $74.60 \pm 1.08^{\mathrm{a}}$ & $15.20 \pm 1.07^{\mathrm{b}}$ & $3.20 \pm 0.58^{\mathrm{d}}$ & $74.0 \pm 1.732^{\mathrm{a}}$ & $16.2 \pm 0.800^{b}$ & $10.6 \pm 0.509^{\circ}$ \\
\hline $\mathrm{C}$ & $73.00 \pm 0.84^{b}$ & $16.80 \pm 0.49^{c}$ & $5.00 \pm 1.67^{\mathrm{e}}$ & $75.0 \pm 0.836^{a}$ & $17.2 \pm 0.583^{c}$ & $11.2 \pm 0.583^{d}$ \\
\hline $\mathrm{D}$ & $70.80 \pm 0.37^{b}$ & $17.80 \pm 0.66^{c}$ & $4.60 \pm 1.21^{\mathrm{e}}$ & $72.8 \pm 0.734^{a}$ & $17.0 \pm 0.547^{c}$ & $11.0 \pm 0.836^{\mathrm{d}}$ \\
\hline
\end{tabular}

Note: ${ }^{a, b, c}$ : means within the same row and column with different superscript were significantly different $(\mathrm{P}<0.05)$ 
222

Chemical properties of the soil samples collected during the rainy and dry seasons

SoilpH during the raining season

The soil of the study site was slightly alkaline across the plots during the raining season. The soil $\mathrm{pH}$ was the highest in plot $\mathrm{C}$ and the lowest in plot $\mathrm{A}$; the remaining plots had intermediate values (Table 2).

\section{Organic matter content during the raining season}

The organic matter content ranged from 2.26 to $2.66 \%$. Organic matter content was highest in plot B, the lowest in plot A and had intermediate values in the other plots. There was no significance difference among all the plots (Table 2).

Total nitrogen and phosphorus during the raining season

The total nitrogen ranged between $0.22-0.26 \%$. The total nitrogen was the lowest in plot A. The results of the analysis showed that there was no significant difference in the total nitrogen content across the four plots (Table 2).

The available phosphorus ranged between 64.14$70.06 \%$. The total phosphorus was the highest in plot C. Plots $\mathrm{C}$ and $\mathrm{D}$ were similar within each other and they were significantly different from the other plots (Table 2).

\section{Exchangeable cations during the raining season}

The exchangeable $\mathrm{K}^{+}$was the lowest at plots $\mathrm{A}$ and $\mathrm{D}$. However, there was no significance difference among all the plots. The exchangeable $\mathrm{Ca}^{2+}$ was the lowest at plot $\mathrm{D}$. There was no significance difference among all the plots. The exchangeable $\mathrm{Na}^{+}$was the highest within plot $\mathrm{D}$, but had intermediate values in the other plots (Table 2).

\section{SoilpH during the dry season}

The soil of the four plots was slightly acidic across the studied plots. Plot $\mathrm{C}$ recorded the highest $\mathrm{pH}$ value. There was no significant difference between plot $\mathrm{B}, \mathrm{C}$ and $\mathrm{D}$, but they were significantly different from plot A (Table 2).

\section{Organic matter content during the dry season}

The organic matter content ranged among 3.2 and $5.2 \%$. The organic matter content was the highest in plot $\mathrm{B}$ and the lowest in plot A. Plot A had significantly lower organic content when compared to plot $\mathrm{B}$, which had the highest organic content. The other plots had intermediate values which were significantly different from each other (Table 2).

\section{Total nitrogen and phosphorus during the dry season}

The total nitrogen ranged between $2.6-3.6 \%$. The total nitrogen was the lowest in plot $\mathrm{D}$ and recorded intermediate values in other plots. Plot D had significantly lower $\mathrm{N}$ content when compared to plot $\mathrm{C}$, which had the highest sodium content. The other plots had intermediate values which were not significantly different from each other except plot A (Table 2).

The available phosphorus ranged from 59.4 to $64.0 \%$, the total phosphorus was high in plots $\mathrm{C}$ and $\mathrm{D}$ and the lowest in plot A. The available phosphorus recorded in plot B was significantly different from the other plots (Table 2).

\section{Exchangeable cations during the dry season}

The exchangeable $\mathrm{K}^{+}$was the highest within plot $\mathrm{B}$ whereas the exchangeable $\mathrm{Ca}^{2+}$ was the highest at plot $\mathrm{A}$, and other plots had intermediate values. Plots B and C recorded the highest exchangeable $\mathrm{Na}^{+}$(Table 2).

\section{Heavy metal content}

In the raining season, there was no significant $(\mathrm{P}>$ 0.05 ) difference among the plots as regard to the value of zinc and nickel among the soil sample taken from the different plots. However, there was significant $(\mathrm{P}<0.05)$ difference in the cadmium, lead and chromium values in soil samples among the different plots. The cadmium content in soil samples from plot B was significantly $(\mathrm{P}<$ 0.05 ) higher than that from plots $C$ and $A$. The soil sample collected at plot B had higher lead content, which was significantly $(P<0.05)$ higher than soil sample collected from plots $C$ and D. There was no significant difference in the nickel values among the plots. The copper content in the soil samples from plot $C$ was significantly higher than that of plots $\mathrm{A}$ and $\mathrm{B}$, which were higher than that of plot $\mathrm{D}$ (Table 3 ).

In the dry season, there was no significant difference among the plots with regard to the value of copper, nickel and lead. There was significant $(P<0.05)$ difference in the

Table 2. Soil chemical properties of the soil sample collected during the rainy and dry seasons

\begin{tabular}{|c|c|c|c|c|c|}
\hline \multirow{2}{*}{ Parameter } & \multirow{2}{*}{ Season } & \multicolumn{4}{|c|}{ Plot } \\
\hline & & A & $\mathrm{B}$ & $\mathrm{C}$ & $\mathrm{D}$ \\
\hline \multirow{2}{*}{ Soil pH $(1: 1)$} & Rainy & $7.32 \pm 0.15^{\mathrm{b}}$ & $7.62 \pm 0.21^{\mathrm{a}}$ & $7.90 \pm 0.13^{\mathrm{a}}$ & $7.84 \pm 0.24^{\mathrm{a}}$ \\
\hline & Dry & $6.20 \pm 0.25^{\mathrm{c}}$ & $6.60 \pm 0.19^{\mathrm{b}}$ & $6.70 \pm 0.13^{\mathrm{b}}$ & $6.60 \pm 0.21^{b}$ \\
\hline \multirow{2}{*}{ Total nitrogen (\%) } & Rainy & $0.22 \pm 0.01^{c}$ & $0.24 \pm 0.02^{c}$ & $0.23 \pm 0.02^{c}$ & $0.26 \pm 0.01^{\mathrm{c}}$ \\
\hline & Dry & $2.74 \pm 0.22^{\mathrm{b}}$ & $3.20 \pm 0.69^{\mathrm{a}}$ & $2.92 \pm 0.19^{\mathrm{b}}$ & $2.61 \pm 0.22^{\mathrm{b}}$ \\
\hline \multirow{2}{*}{ Total phosphorus (PPM) } & Rainy & $65.13 \pm 2.57^{b}$ & $64.52 \pm 1.88^{b}$ & $70.06 \pm 1.41^{\mathrm{a}}$ & $69.84 \pm 0.54^{a}$ \\
\hline & Dry & $59.43 \pm 3.46^{\mathrm{d}}$ & $60.62 \pm 1.36^{c}$ & $64.0 \pm 1.52^{\mathrm{b}}$ & $64.0 \pm 1.92^{\mathrm{b}}$ \\
\hline \multirow{2}{*}{ Potassium $(\mathrm{Cmol} / \mathrm{kg})$} & Rainy & $0.22 \pm 0.02^{\mathrm{a}}$ & $0.26 \pm 0.02^{\mathrm{a}}$ & $0.26 \pm 0.06^{\mathrm{a}}$ & $0.22 \pm 0.02^{\mathrm{a}}$ \\
\hline & Dry & $0.11 \pm 0.01^{b}$ & $0.30 \pm 0.22^{\mathrm{a}}$ & $0.11 \pm 0.00^{\mathrm{b}}$ & $0.11 \pm 0.01^{\mathrm{b}}$ \\
\hline \multirow{2}{*}{ Calcium (Cmol/kg) } & Rainy & $0.75 \pm 0.02^{\mathrm{d}}$ & $0.75 \pm 0.03^{\mathrm{d}}$ & $0.77 \pm 0.01^{\mathrm{d}}$ & $0.73 \pm 0.04^{\mathrm{d}}$ \\
\hline & Dry & $4.62 \pm 1.29^{\mathrm{a}}$ & $3.34 \pm 0.25^{\mathrm{b}}$ & $3.44 \pm 0.26^{\mathrm{b}}$ & $2.12 \pm 0.74^{\mathrm{c}}$ \\
\hline \multirow{2}{*}{ Sodium $(\mathrm{Cmol} / \mathrm{kg})$} & Rainy & $0.10 \pm 0.01^{\mathrm{a}}$ & $0.12 \pm 0.01^{\mathrm{a}}$ & $0.10 \pm 0.01^{\mathrm{a}}$ & $0.13 \pm 0.01^{\mathrm{a}}$ \\
\hline & Dry & $0.09 \pm 0.00^{\mathrm{a}}$ & $0.10 \pm 0.01^{\mathrm{a}}$ & $0.10 \pm 0.01^{\mathrm{a}}$ & $0.08 \pm 0.02^{\mathrm{a}}$ \\
\hline \multirow{2}{*}{ Organic matter (\%) } & Rainy & $2.26 \pm 0.15^{\mathrm{c}}$ & $2.66 \pm 0.08^{c}$ & $2.33 \pm 0.20^{c}$ & $2.64 \pm 0.17^{c}$ \\
\hline & Dry & $3.21 \pm 0.31^{b}$ & $5.22 \pm 0.24^{\mathrm{a}}$ & $3.61 \pm 0.53^{b}$ & $4.43 \pm 0.29^{\mathrm{ab}}$ \\
\hline
\end{tabular}

Note: ${ }^{a, b, c}$ : means within the same column with different superscript were significantly different $(\mathrm{P} \leq 0.05)$ 
Table 3. Heavy metals content of soil samples collected during rainy and dry seasons

\begin{tabular}{|c|c|c|c|c|c|}
\hline \multirow{2}{*}{ Parameter (ppm) } & \multirow{2}{*}{ Season } & \multicolumn{4}{|c|}{ Plot } \\
\hline & & $\mathrm{A}$ & B & $\mathrm{C}$ & $\mathrm{D}$ \\
\hline \multirow{2}{*}{ Zinc } & Rainy & $19.24 \pm 1.86^{\mathrm{a}}$ & $20.17 \pm 2.80^{\mathrm{a}}$ & $20.78 \pm 0.97^{\mathrm{a}}$ & $19.14 \pm 0.74^{\mathrm{a}}$ \\
\hline & Dry & $11.01 \pm 0.59^{\mathrm{b}}$ & $10.81 \pm 0.54^{\mathrm{ab}}$ & $8.32 \pm 0.68^{\mathrm{a}}$ & $4.50 \pm 1.42^{b}$ \\
\hline \multirow{2}{*}{ Cadmium } & Rainy & $0.32 \pm 0.02^{b}$ & $0.51 \pm 0.06^{a}$ & $0.32 \pm 0.02^{b}$ & $0.37 \pm 0.07^{\mathrm{b}}$ \\
\hline & Dry & $0.11 \pm 0.01^{\mathrm{c}}$ & $0.11 \pm 0.01^{\mathrm{c}}$ & $0.11 \pm 0.00^{c}$ & $0.06 \pm 0.02^{\mathrm{d}}$ \\
\hline \multirow{2}{*}{ Lead } & Rainy & $1.10 \pm 0.07^{\mathrm{ab}}$ & $1.27 \pm 0.13^{\mathrm{a}}$ & $0.72 \pm 0.04^{c}$ & $1.06 \pm 0.01^{\mathrm{b}}$ \\
\hline & Dry & $0.51 \pm 0.16^{c}$ & $0.72 \pm 0.08^{\mathrm{b}}$ & $0.82 \pm 0.04^{\mathrm{a}}$ & $0.81 \pm 0.05^{\mathrm{a}}$ \\
\hline \multirow{2}{*}{ Chromium } & Rainy & $0.08 \pm 0.00^{\mathrm{ab}}$ & $0.07 \pm 0.00^{\mathrm{b}}$ & $0.07 \pm 0.00^{\mathrm{b}}$ & $0.08 \pm 0.00^{\mathrm{ab}}$ \\
\hline & Dry & $0.02 \pm 0.00^{\mathrm{a}}$ & $0.01 \pm 0.00^{\mathrm{b}}$ & $0.02 \pm 0.00^{\mathrm{a}}$ & $0.01 \pm 0.01^{\mathrm{b}}$ \\
\hline \multirow{2}{*}{ Nickel } & Rainy & $0.01 \pm 0.00^{\mathrm{a}}$ & $0.01 \pm 0.00^{\mathrm{a}}$ & $0.01 \pm 0.00^{\mathrm{a}}$ & $0.01 \pm 0.00^{\mathrm{a}}$ \\
\hline & Dry & $0.10 \pm 0.02^{\mathrm{a}}$ & $0.21 \pm 0.01^{\mathrm{a}}$ & $0.10 \pm 0.01^{\mathrm{a}}$ & $0.10 \pm 0.01^{\mathrm{a}}$ \\
\hline \multirow{2}{*}{ Copper } & Rainy & $7.81 \pm 0.83^{\mathrm{a}}$ & $8.41 \pm 0.39^{\mathrm{a}}$ & $10.30 \pm 0.65^{a}$ & $6.61 \pm 0.35^{b}$ \\
\hline & Dry & $0.73 \pm 0.08^{\mathrm{b}}$ & $0.72 \pm 0.03^{\mathrm{b}}$ & $0.71 \pm 0.02^{\mathrm{b}}$ & $0.51 \pm 0.11^{\mathrm{c}}$ \\
\hline
\end{tabular}

Note: ${ }^{\text {a, b, c }}$ : Means within the same column with different superscript were significantly different $(\mathrm{P} \leq 0.05)$.

cadmium, zinc and chromium value in soil samples among the different plots. The cadmium content in soil samples from plots $\mathrm{A}, \mathrm{B}$ and $\mathrm{C}$ was significantly $(\mathrm{P}<0.05)$ higher than that from plot $\mathrm{D}$. The soil sample collected from plot A had higher zinc content, which was significantly $(\mathrm{P}<$ 0.05 ) higher than soil sample collected from plot D. The level of chromium in plots $\mathrm{B}$ and $\mathrm{D}$ was significantly $(\mathrm{P}<$ 0.05 ) higher than that of plots $A$ and $C$. However, there was no significant difference in the nickel values among the plots (Table 3).

\section{Discussion}

\section{Soilproperties}

The availability of essential elements is known to affect plant species richness, the yield and quality of crops (Heitholt et al., 2002; Parsons et al., 2007). Nutrient availability varies during the growing seasons, depending on the prevailing environment conditions and some characteristics of the soil (Cancela et al., 2002; Strahm and Harrison, 2007). Nonetheless, the status and behaviour of nutrients in soil are difficult to predict (Moral et al., 2002; Moreno-Caselles et al., 2005). The results obtained within the current study showed that plot A was richer in clay and silt soil than plots B, C and Dm which are richer only in clay. More clayey soils generally tend to contain higher levels of organic matter, mainly because of the tendency of clays to slow down microbial degradation of organic matter as clays form clay-humus complexes with organic matter. This process could be responsible for the higher organic matter recorded in all the plots under study. Moffat (2001) reported that trees may increase the organic matter coupled with the organic carbon content of the soil. Therefore, the high organic matter content recorded in plot B may be due in part to the fact that the dominant tree species (Theobroma cacao stands) in this plot was spared, probably because of its economic value; also, in part due to the presence of a large amount of fallen leaves from the dominant $T$. cacao stands that were found in the plot, it has been noted that litter fall tends to increase the organic matter content of the soil.

Furthermore, poorly drained soils typically accumulate higher levels of soil organic matter than well-drained soils due to poor aeration, causing a decline in soil oxygen concentrations. This observation is in agreement with that of Brady and Weil (1999) who reported that soils high in clay and silt are generally higher in soil organic matter content than sandy soils. Species that can quickly reestablish in a soil with high organic matter content due to high level of clay may dominate this environment.

Soil $\mathrm{N}$ increase is very important in degraded land rehabilitation projects, since, according to Francis and Read (1994), it enhances the capacity of the system to support a more complex community. According to Li et al. (2003), moister soils tend to have higher mineral soil $\mathrm{C}$ and $\mathrm{N}$ as well as higher $\mathrm{N}$ mineralization rates than drier soils; therefore, the higher $\mathrm{N}$ observed in the study may also be attributed to high soil moisture content of the plots.

Available phosphorus was high in all the plots especially in plot C. This can be attributed to the presence of phosphorus fixing species (Davidson et al., 2004) such as Alchornea cordifolia on the site. This conformed to the report of Kang et al. (1984) that species of Alchornea cordifolia and Gliricidia sepium have high potential of fixing phosphorus content when present in the soil.

Soil $\mathrm{pH}$ influences nutrient uptake, nutrient availability and species diversity. Soil $\mathrm{pH}$ values at the extremes $(<4.0$ and $>8.5)$ can make some nutrient toxic and others unavailable to plants. At lower $\mathrm{pH}$ values $(<4.5)$, aluminium, iron and manganese are readily available for plant uptake. At higher $\mathrm{pH}$ levels (> 5.5), calcium and potassium are over abundant (Andrew and Roberts, 2002). Most plants grow best where the soil is slightly acidic, in the range of $\mathrm{pH} 5.8$ to 7.0 and since the $\mathrm{pH}$ values (5.58-7.8) obtained in this study were within this range, the plants growing in these vegetation types were provided with good growing conditions, as reflected in the physiognomy of all the plots under consideration. However, the average potassium (0.11\%-0.28\%) and calcium (0.4\%-0.82\%) contents obtained, both having relatively low values, may be attributed to the disturbances which affect floristic composition of the sites.

\section{Seasonal dynamics and soil properties}

The maintenance of soil fertility in tropical forest ecosystems is achieved by high and rapid circulation of nutrients through the fall and decomposition of litter which is a function of the season (Spain, 1984; Ola-Adams and Egunjobi, 1992; Oliveira and Lacerola, 1993; Moraes et al., 1999). Seasonal variations affect the availability of nutrients from the soil to plant species (Ezenwa et al., 1995). From 
224

the data analyzed, it was revealed that the physico-chemical properties of soil in the study plots varied across the plots, but did not significantly vary within seasons. The sand content obtained from each of the plots ranged between 70.80 and $74.60 \%$ in the rainy season; thus, the data did not differ significantly from the sand content obtained during the dry season (72.8 to $75.2 \%)$, although the sand content obtained for each plot during the two seasons at $0-20 \mathrm{~cm}$ depth was high and these corroborate with the work of Lipika et al. (2013), who observed nearly 90\% sand content in the polluted soil around Bubana chemical industry. The results obtained hereby also revealed that the clay content obtained during the dry season was higher than that of the rainy season, but no significant difference between the two seasons were noted. The silt contents obtained in plots B, C and $\mathrm{D}$ during the rainy season showed a clear significant difference from that of dry season, with dry season having high silt content. However, the similarity in the textural composition revealed that the soils from all plots were derived from the same parent material and the percentage at which they were available depends on the season.

The soil $\mathrm{pH}$ of all the plots under consideration for the two seasons revealed that the soil $\mathrm{pH}$ range was 5.7-7.9 and fall within the range reported by Oyenuga (1979) for soil in Ife area. He reported that the general surface horizon are neutral to weakly acidic in reaction. The $\mathrm{pH}$ during the rainy season ranged between 7.3 and 7.9 , while during the dry season it ranged between 5.7 and 6.7, respectively. These showed a clear variation in $\mathrm{pH}$ values during the two seasons and also similar to what was observed by Ilechukwu and Osuji (2013). The seasonal variation observed in these results may also be attributed partially to the changing in concentration of the salt in the soil solution. Soil pH has a direct effect on the availability of most of the nutrients and is important for proper nutrient management. The $\mathrm{pH}$ values obtained in some of the plots was within the recommended $\mathrm{pH}$ range (6.0-7.5) for optimum nutrient availability in soil (Fagbote and Olanipekun, 2011).

Organic matter is needed for the chemical well being of the plants and soil fertility status because it is the source of nearly all the nitrogen and most of the phosphorus in some soils (Craul, 1992). In the present study, the value of organic matter obtained differed within seasons. The values observed in this study were similar to those of Lipika $e t a l$. (2013). It could also be noted that the values of organic matter obtained during the dry season were higher than those of the rainy season. The results showed that seasons are highly significant to both calcium and nitrogen content availability in the soil because the mean value obtained for the two parameters during the dry season was higher than that of the rainy season, but not significant for phosphorus, potassium and sodium availability in the soil. This interpretation was similar to the work of Ogundele (2012) who observed that seasons are highly significant to both organic and nitrogen content availability in the soil, but not significant to phosphorus, potassium and sodium availability in the soil.

Heavy metal distribution in the soil varied with the two seasons, with the highest level of $\mathrm{Zn}, \mathrm{Cd}, \mathrm{Pb}, \mathrm{Cr}$ and $\mathrm{Cu}$ found during the rainy season respectively, while for $\mathrm{Ni}$, no significant difference was noted within seasons. This was similar to the observation of Kabir and Bouhadjera (2011) in their study of effects of heavy metals pollution in soil and plant in the industrial area of West Algeria. This implies that the majority of these heavy metals were more readily available during the rainy season than during the dry season.

\section{Conclusions}

The study revealed that the physicochemical properties of soil in focus varied across the plots, which may be a consequence of the gradient created by the citing of iron smelting factory, even though the data did not significantly vary within the dry and rainy season. Furthermore, high organic matter was recorded in all the plots; this might be due to the fact that the study area was rich in clay. More clayey soils generally tend to contain higher levels of organic matter, mainly because of the tendency of clays to slow down microbial degradation of organic matter and form clay-humus complexes. Also, the heavy metal distribution varied within the two seasons, as most of the metals showed highest level of concentration in the rainy season. However, there was no enough evidence in the current study to demonstrate the possible implication of variation in soil chemical properties as a result of industrial activities on the surrounding standing vegetation. Therefore, it may be recommended that further studies on the aforementioned key point, in order to ascertain the possible consequence of alteration in soil chemical properties on nearby vegetation, are needed and thus set priorities in conservation and restoration of industrially degraded vegetation.

\section{References}

Andrew J, Roberts C (2002). Soil pH and species suitability in Mississippi. Extension Service of Mississippi State University.

Aweto AO, Ekuigbo UE (1994). Effects of oil palm plantations on tropical forest soils in South Western Nigeria. The Indonesia Journal of Geography 26:51-59.

Benayas JMR, Sánchez-Colomer MG, Escudero A (2004). Landscape and field-scale control of spatial variation of soil properties in Mediterranean montane meadows. Biogeochemistry 69(2):207225

Bouyoucos GJ (1951). A calibration of the hydrometer method for making mechanical analysis of soils. Agronomy Journal 43:434438.

Brady NC, Weil RR (1999). The nature and properties of soils. 12th ed. MacMillan, New York.

Bray RH, Kurtz LT (1945). Determination of total, organic and available forms of phosphorus in soils. Soil Science 59:39-48.

Cancela RC, De Abreu CA, Paz-Gonzalez A (2002). DTPA and Mehlich-3 micronutrient extractability in natural soils. Communications in Soil Science and Plant Analysis 33:28792893.

Craul PJ (1992). Urban soil in landscape design. John Wiley and Sons Inc, New York, NY.

Davidson EA, de Carvalho CJR, Vieira ICG, Figueiredo RO, Moutinho P, Ishida FY, dos Santos P, Guerrero JB, Kalif K, Saba RT (2004). Nitrogen and phosphorus limitation of biomass growth in a tropical secondary forest. Ecological Applications $14(\mathrm{sp} 4): 150-163$.

Ezenwa I, Reynolds L, Akenova, ME, Atta-Akrah AN, Cobbina J 
(1995). Cutting management of alley croped leucaena/glincidaGuinea grass mixture for forage production in South Western Nigeria. Agroforestry System 29(1):9-20.

Fagbote EO, Olanipekun EO (2011). Speciation of heavy metals in sediment of Agbabu Bitumen deposit area, Nigeria. Journal of Applied Science and Environmental Management 14(4):47-51.

Francis R, Read DJ (1994). The contributions of mycorrhizal fungi to the determination of plant community structure. Plant Soil 159:11-25.

Heitholt JJ, Sloan JJ, MacKown CT (2002). Copper, manganese, and zinc fertilization effects on growth of soybean on a calcareous soil. Journal of Plant Nutrition 25:1727-1740.

Ilechukwu I, Osuji LC (2013). Physico-chemical characteristics of soils within the vicinity of a hot mix asphalt (HMA) plant in Obigbo, Port Harcourt, Nigeria. Applied Science Research 5(3):184-192.

Jamieson T, Gordon T, Cochrane L, Patterson G (2002). Fundamental aspects of soil-water-plant relationships. Technical Report, Resource Stewardship Division, NS Department of Agriculture and Fisheries-Truro, Nova Scotia.

Kabir T, Bouhadjera K (2011). Effects of heavy metals pollution in soil and plant in the industrial area, West Algeria. Journal of the Korean Chemical Society 55(6):1018-1023.

Kang BT, Wilson GF, Lawson TL (1984). Alley cropping as a stable alternative to shifting cultivation. International Institute of Tropical Agriculture, Ibadan, Nigeria.

Li QC, Allen HL, Wilson CA (2003). Nitrogen mineralization dynamics following the establishment of a loblolly pine plantation. Canadian Journal of Forest Research 33(2):364-374.

Lipika P, Dipti R, Lipika B, Ashwini N, Saswati M, Sambit S (2013). Physico chemical and heavy metal characterization of soil from industrial Belt of Cuttach, Orissa. Asian J Exp Biol Sci 4(2):219225.

Marx J, Bary A, Jackson S, McDonald D, Wescott H (1999). The relationship between soil and water - how soil amendments and compost can aid in salmon recovery. Soils for Salmon pp 1-18.

Moffat AJ (2001). Increasing woodland in urban areas in the UKmeeting ecological and environmental standards. The International Forestry Review 1:198-205.

Moraes R, Delitti WBC, Struffaldi-De Vuono Y (1999). Litter and nutrient content in two Brazilian Tropical Forests. Brazilian Journal of Botany 22(1):9-16

Moral R, Moreno-Caselles J, Perez-Murcia M, Perez-Espinosa A (2002). Improving the micronutrient availability in calcareous soils by sewage sludge amendment. Communications in Soil
Science and Plant Analysis 33(15-18):3015-3022.

Moreno-Caselles J, Moral R, Perez-Murcia MD, Perez-Espinosa A, Paredes C, Agullo E (2005). Fe, Cu, Mn, and $\mathrm{Zn}$ input and availability in calcareous soils amended with the solid phase of pig slurry. Communications in Soil Science and Plant Analysis 36:525-534.

Ogundele AO (2012). Variation in the physico-chemical properties of Badagry and Ikorodu Soils, Lagos Nigeria. International Journal of Humanities and Social Science 2(8):244-258.

Ola-Adams BA, Egunjobi JK (1992). Effects of spacing on litter fall and nutrient content in stands of Tectona grandis Linn. f. and Terminalia superba Engl. \& Diels. African Journal of Ecology 30:18-32.

Oliveira R, Lacerola LD (1993). Produção e composição química da serapilheira na Floresta da Tijuca (RJ). Revista Brasileira de Botânica 16(1):93-99.

Oyenuga VA (1979). Agriculture in Nigeria. Food and Agriculture Organization of the United Nations. FAO, Rome, Italy.

Parsons KJ, Zheljazkov VD, MacLeod J, Caldwell CD (2007). Soil and tissue phosphorus, potassium, calcium, and sulphur as affected by dairy manure application in a no-till corn, wheat, and soybean rotation. Agronomy Journal 99:1306-1316.

Peverill KI, Sparrow LA, Reuter DJ (1999). Soil analysis: an interpretation manual. CSIRO, Collingwood, Australia pp 170174.

Rai MM (2002). Principles of soil science. Macmillan, India pp 38-91.

Rodriguez-Iturbe I (2000). Ecohydrology: a hydrologic perspective of climate-soil-vegetation dynamics. Water Resources Research 36(1):3-9.

Smith CJ, Hopmans P, Cook FJ (1996). Accumulation of Cr, Pb, Cu, $\mathrm{Ni} \mathrm{Zn}$ and $\mathrm{Cd}$ in soil following irrigation with untreated urban effluents in Australia. Environmental Pollution 94(3):317-323.

Spain AV (1984). Litter fall and the standing crop of litter in three tropical Australia rain forests. The Journal of Ecology pp 947-961.

Strahm BD, Harrison RB (2007). Mineral and organic matter controls on the sorption of macronutrient anions in variablecharge soils. Soil Science Society of America Journal 71:19261933.

Van der Maarel E (2004). Vegetation ecology, Blackwell, Oxford, UK. 